ANNA ŚWIDURSKA

Uniwersytet im. Adama Mickiewicza w Poznaniu

\title{
Kształtowanie się przemysłu wysokiej techniki w Polsce
}

W epoce kształtowania się społeczeństwa informacyjnego, tworzącego nową organizację życia zbiorowego, która trwa i rozwija się dzięki otwartemu dostępowi do informacji oraz realnej możliwości komunikowania się, wzrost gospodarczy staje się coraz bardziej uzależniony od produkcji, dystrybucji i wykorzystania wiedzy (por. Woroniecki 2003, Chojnicki, Czyż 2006, Kobyłko, Morawski 2006, Przybyszewski 2007, Welfe 2007, Wieloński 2007, Zioło 2008). Współczesna rewolucja przemysłowa jest efektem zapoczątkowanej w latach 70. XX wieku integracji nauki i przemysłu. Nowa, dominująca rola nauki w rozwoju gospodarczym i cywilizacyjnym przyczynia się do powiększenia prestiżu nauk technologicznych, postęp w tej dziedzinie badań nie jest jednak izolowany od badań podstawowych i stosowanych.

Wraz z nowym ładem ekonomicznym, opartym na zaawansowanych technologiach, zmieniają się zasady funkcjonowania i organizacji przemysłu. Innowacyjność przemysłu określa w coraz większym stopniu przewagę konkurencyjną państw, regionów, przedsiębiorstw.

Innowacyjny charakter produktów ma jednak swoje ramy czasowe, podobnie jak ich przewaga konkurencyjna (Chojnicki, Czyż 2006, s. 14). Istotą współczesnego przedsiębiorstwa jest więc pozyskiwanie i wykorzystywanie wiedzy praktycznie w każdym aspekcie jego funkcjonowania. Wiedza staje się siłą napędową gospodarki, a nie gospodarka wiedzy (Toffler 2003, s. 403). Uważa się, że „sukces jednostek, przedsiębiorstw, regionów i krajów będzie bardziej przejawem ich zdolności do kształcenia niż czegokolwiek innego" (OECD 2000, s. 29). „Kształcenie w ujęciu gospodarki opartej na wiedzy pojmuje się jako proces, który polega na uzyskiwaniu kwalifikacji i umiejętności (a nie wyłącznie wiedzy), prowadzących do osiagnięcia większego sukcesu w realizacji celów jednostek lub organizacji. Z punktu widzenia kształcenia gospodarka oparta na wiedzy ma stanowić gospodarkę ludzi uczących się" (Chojnicki 2003, s. 319). Na tych założeniach oparte jest pojęcie kapitału ludzkiego. Ujęcie to ma charakter komplementarny w stosunku do poglądu, że gospodarkę opartą na wiedzy wyznacza tylko działalność innowacyjna:

Kształtowanie gospodarki opartej na wiedzy - twierdzą Chojnicki i Czyż (2006, s. 19) - warunkują bowiem, w sposób konieczny, chociaż niewystarczający, wysokie kwalifikacje i stałe uczenie się w dziedzinie wiedzy technologicznej i zarządzania (biznesu). Kreatywność pracowników w obu tych dziedzinach staje się najważniejszym czynnikiem konkurencyjności oraz przekształceń postmodernizacyjnych organizacji gospodarki. 
Szczególną rolę w kształtowaniu się konkurencyjności i osiąganiu sukcesu ekonomicznego poszczególnych rodzajów przemysłu danego kraju Porter (1990, s. 72, cyt. za Chojnickim 1999, s. 370) upatruje w kontekście lub środowisku działalności gospodarczej:

poszczególne uwarunkowania, jak i ich system tworzą kontekst, w którym przedsiębiorstwa w danym kraju rodzą się i współzawodniczą: możność wykorzystania zasobów i umiejętności niezbędnych do czerpania korzyści z konkurencji w przemyśle; informacja, która określa, jakie sposobności są postrzegane i w jakim kierunku zasoby te i umiejętności są wykorzystywane; cele właścicieli, menedżerów i pracowników, dotyczące konkurencji oraz najważniejsze - nacisk na przedsiębiorstwa, aby inwestowały i wprowadzały innowacje. [...] Ostatecznie narody (kraje) osiagają sukcesy w poszczególnych rodzajach przemysłu, ponieważ ich środowisko jest najbardziej dynamiczne i najszybciej dające odpowiedź oraz stymulujące i zmuszające przedsiębiorstwa, aby powiększyć i rozszerzyć swoje korzyści w czasie.

Dla Polski obszary produkcji oparte na zaawansowanych technologiach wciąż stanowią jedynie wyzwanie. Te obszary, które pojawiły się w ostatnich latach, znacznie odbiegają od docelowego modelu tego rodzaju kompleksów w wysoko rozwiniętych gospodarczo i cywilizacyjnie krajach zachodnich. Jak zaznacza Kukliński (2001, s. 17), „polska gospodarka musi przekształcić się w GOW. W przeciwnym przypadku gospodarka polska stanie się gospodarką II i III klasy".

W nawiązaniu do rozwoju i przemian gospodarki dokonujących się pod wpływem nauki oraz zważywszy na szczególną rolę przemysłu wysokiej techniki w wypracowaniu i utrzymaniu przewagi konkurencyjnej danego kraju, celem prezentowanego opracowania jest analiza i ocena efektywności rozwoju tego rodzaju działalności w Polsce. Zakres czasowy analizy obejmuje lata 1999-2006.

\section{POJĘCIE I OPERACYJNE UJĘCIE PRZEMYSŁU WYSOKIEJ TECHNIKI}

Przemysł wysokiej techniki (high-tech manufacturing sectors) tworzy z usługami wysokiej techniki (high-tech services) ewentualnie z usługami o wysokim nasyceniu wiedza (knowledge intensive services) sektor GOW, który stanowi „tę sferę lub typ gospodarki, której rozwój dokonuje się pod dominującym wpływem nauki lub wiedzy naukowej przeważającym nad innymi czynnikami” (Chojnicki, Czyż 2006, s. 18).

Według definicji OECD sekcje wysokiej techniki wyróżnia się na podstawie wskaźnika intensywności bezpośrednich i pośrednich nakładów na działalność badawczo-rozwojową $(\mathrm{B}+\mathrm{R})$. Definiując sektor high-tech można ponadto uznać, że charakteryzuje się on: wysokim poziomem zatrudnienia pracowników naukowo-technicznych, intensywną współpracą z ośrodkami naukowo-badawczymi, szybkim procesem starzenia się opracowywanych produktów i technologii, wysoką dynamiką wymiany zasobów w zakresie infrastruktury technicznej oraz efektami działalności innowacyjnej w postaci licznych patentów i licencji (patrz np. Grudzewski, Hejduk 2008, s. 31).

W prezentowanym opracowaniu podstawę empirycznej charakterystyki przemysłu wysokiej techniki stanowi wykaz działów (branż) produkcyjnych wysokiej techniki według klasyfikacji PKD obowiązującej w 2006 roku (polskiej wersji klasyfikacji Unii Europejskiej NACE). Do przemysłu wysokiej techniki zalicza się: produkcję chemikaliów (D24), produkcję maszyn i urządzeń (D29), produkcję maszyn biurowych i komputerów (D30), produkcję 
maszyn i aparatury elektrycznej (D31), produkcję sprzętu i urządzeń radiowych, telewizyjnych i telekomunikacyjnych (D32), produkcję instrumentów medycznych, precyzyjnych i optycznych, zegarów i zegarków (D33), produkcję pojazdów mechanicznych, przyczep i naczep (D34), produkcję pozostałego sprzętu transportowego (D35). Dokonując oceny struktury przemysłu wysokiej techniki i poziomu jego rozwoju w nawiązaniu do światowych trendów rozwoju branż opartych na osiagnięciach nauki i techniki, przyjęto za podstawę listę branż i produktów wysokiej techniki ustaloną przez OECD. W tym ujęciu przemysł wysokiej techniki obejmuje branże: D30, D32, D33, produkcję wyrobów farmaceutycznych (24.4), produkcję statków powietrznych i kosmicznych (35.3).

\section{DYNAMIKA ROZWOJU PRZEMYSŁU WYSOKIEJ TECHNIKI}

Zmiany technologiczne są jednym z najważniejszych czynników mających wpływ na reguły konkurencji. Odgrywają one kluczową rolę zarówno w procesach prowadzących do zmian strukturalnych w obrębie danej branży, jak i w procesie powstawania nowych branż (Porter 2006, s. 211). W polskiej gospodarce luka technologiczna nadal powiększa się. Świadczą o tym m.in.: 1. obniżenie poziomu zdolności konkurencyjnej wielu polskich produktów na rynku światowym, 2. wyraźna przewaga konkurencyjna wyrobów zagranicznych, pochodzących niekiedy z krajów o co najwyżej średnim poziomie rozwoju, 3. zmniejszenie produktywności wielu stosowanych w polskim przemyśle technologii zagranicznych, 4. nadmierne zużycie materiałów, surowców i energii, 5. nadmierna różnorodność wytwarzanych wyrobów w jednym przedsiębiorstwie, co utrudnia specjalizację i redukcję kosztów jednostkowych (Grudzewski, Hejduk 2008, s. 48). Dokonując analizy różnicy poziomu kreowania produktów i sposobów ich wytwarzania, można uwzględnić stopień tzw. zapóźnienia technologicznego produktów, obliczany na podstawie oceny, ile lat dzieli Polskę do osiagnięcia pozycji światowych liderów w innowacjach w poszczególnych dziedzinach (Grudzewski, Hejduk 2008, s. 49). W odniesieniu do prezentowanych w tabeli 1 grup produktów stopień tzW. zapóźnienia technologicznego często przekracza 5 lat.

Tab. 1. Stopień zapóźnienia technologicznego wybranych grup produktów wysokiej techniki w Polsce

\begin{tabular}{|l|c|c|c|c|c|}
\hline \multirow{2}{*}{ Grupy produktów } & \multirow{2}{*}{$\begin{array}{c}\text { Liczba } \\
\text { badanych } \\
\text { produktów }\end{array}$} & \multicolumn{2}{c|}{ Niższy poziom opóźnienie } & \multirow{2}{*}{$\begin{array}{c}\text { Jednakowy } \\
\text { poziom }\end{array}$} \\
\cline { 5 - 6 } & 2 & 1 & 1 & - & - \\
\hline Roboty przemysłowe & 7 & 3 & 1 & 2 & 1 \\
\hline Maszyny energetyczne & 1 & 1 & - & - & - \\
\hline Tranzystory mikrofalowe & 1 & 1 & - & - & - \\
\hline Mikrofalowe układy scalone & 1 & 1 & - & - & - \\
\hline Satelitarne odbiorniki telewizyjne & 9 & 7 & - & - & 2 \\
\hline Aparaty elektryczne & 4 & 1 & 2 & 1 & - \\
\hline Maszyny elektryczne & & & & & \\
\hline
\end{tabular}

Źródło: Kasprzak, Pelc (1999); Grudzewski, Hejduk (2008) 
Wśród 2017 przedsiębiorstw ${ }^{1}$ reprezentujących sekcję produkcyjną wysokiej techniki, funkcjonujących w 2007 roku, 27\% rozpoczęło działalność w latach 1999-2006 (ryc. 1). Prawie 60\% przedsiębiorstw powstało po 1994 roku, w którym rozpoczęła się faza rosnącej stabilizacji makroekonomicznej i szybkiego wzrostu gospodarczego.

W 2006 roku wartość produkcji sprzedanej przemysłu wysokiej techniki wynosiła 226,1 mld zł w stosunku do 108,2 mld w 1999 roku. Wskaźnik dynamiki produkcji sprzedanej $\left(\mathrm{W}_{\mathrm{d}}=209\right)$ był nieznacznie wyższy od średniej krajowej $\left(\mathrm{W}_{\mathrm{d}}=185\right)$. Krzywa dynamiki produkcji sprzedanej podlegała względnie niewielkim wahaniom (ryc. 2). Jednocześnie przeprowadzona analiza ujawniła niewielkie zróżnicowanie dynamiki produkcji sprzedanej przemysłu wysokiej techniki w zależności od wielkości przedsiębiorstw. Przyjmując podział przedsiębiorstw na trzy klasy wielkości (49 i mniej, 50-249, 250 i więcej) produkcja sprzedana wzrosła odpowiednio o 85\%,109\% i 114\%. W ostatnich latach kontynuowana była tendencja dynamicznego rozwoju przedsiębiorstw specjalizujących się w produkcji pojazdów mechanicznych, prowadzących jednak obecnie działalność w otoczeniu kreującym niewiele szans oraz stwarzającym szereg zagrożeń. W latach 1999-2006 produkcja sprzedana tej branży wzrosła o $160 \%$ (tab. 2).

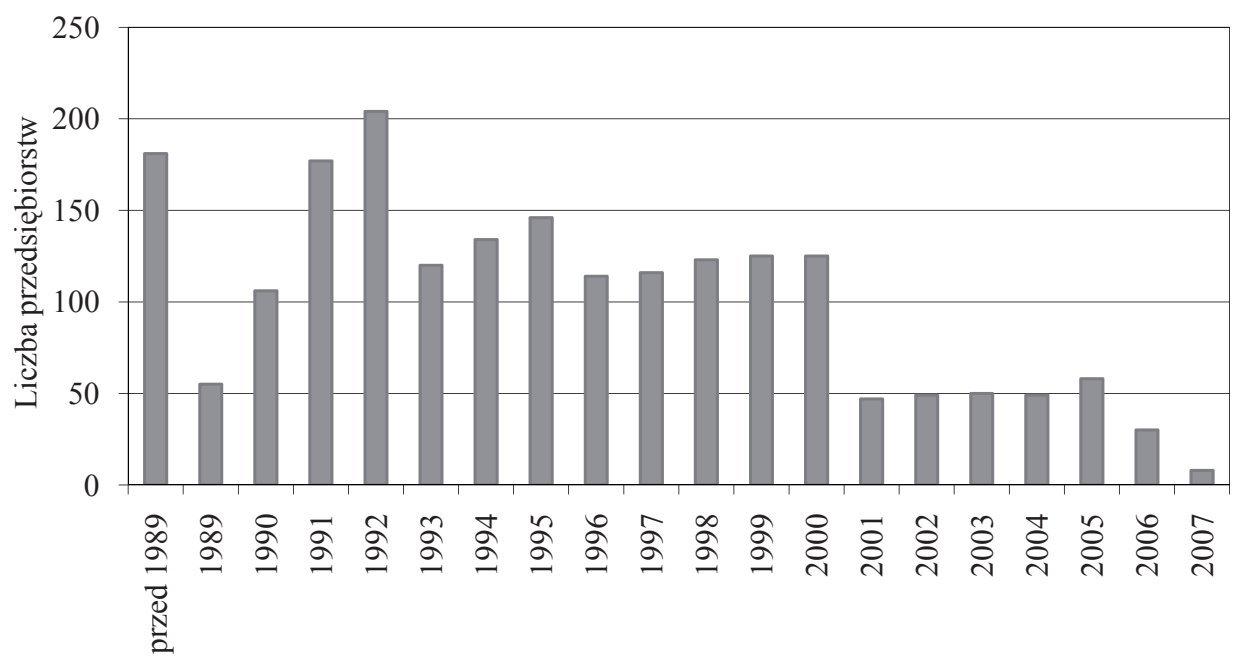

Ryc. 1. Rok założenia przedsiębiorstw produkcyjnych wysokiej techniki zatrudniających powyżej 49 osób (stan w maju 2007 r.)

Źródło: opracowanie własne na podstawie niepublikowanych materiałów statystycznych GUS

W 2006 roku przeciętne zatrudnienie w przemyśle wysokiej techniki wynosiło 638,8 tys. osób. W uwzględnionym okresie przeciętne zatrudnienie spadło o $11 \%$, tj. 82,1 tys. osób. Od 2003 roku krzywa dynamiki wykazuje trend rosnący. W latach 2003-2006 przeciętne zatrudnienie wzrosło o $10 \%$, tj. 56,8 tys. osób. Silniejszym wahaniom podlegała krzywa dynamiki zatrudnienia w działalności badawczo-rozwojowej w przemyśle wysokiej techniki. W latach 1999-2002 nastapił spadek zatrudnienia o 40\%, natomiast w latach 2002-2006 wzrost o $33 \%$ (ryc. 2, 3).

1 Dotyczy przedsiębiorstw zatrudniających powyżej 49 osób (źródło: niepublikowane materiały statystyczne GUS). 
Tab. 2. Rozwój przemysłu wysokiej techniki w latach 1999-2006 na podstawie wybranych mierników według branż

\begin{tabular}{|c|c|c|c|c|}
\hline Branże & Lata & $\begin{array}{l}\text { Produkcja sprzedana } \\
\qquad(\mathrm{w} \text { mln } \mathrm{zl})\end{array}$ & $\begin{array}{l}\text { Przeciętne zatrudnienie } \\
\text { (w tys.) }\end{array}$ & $\begin{array}{c}\text { Eksport } \\
\text { (w mln zł) }\end{array}$ \\
\hline D24 & $\begin{array}{l}1999 \\
2003 \\
2006\end{array}$ & $\begin{array}{l}23982,5 \\
35584,4 \\
47432,2\end{array}$ & $\begin{array}{r}121,5 \\
98,6 \\
102,2\end{array}$ & $\begin{array}{r}6709,6 \\
10457,7 \\
16229,0\end{array}$ \\
\hline D29 & $\begin{array}{l}1999 \\
2003 \\
2006\end{array}$ & $\begin{array}{l}20698,2 \\
26520,1 \\
42446,5\end{array}$ & $\begin{array}{l}240,9 \\
175,8 \\
184,8\end{array}$ & $\begin{array}{r}5471,1 \\
9349,4 \\
16365,5\end{array}$ \\
\hline D30 & $\begin{array}{l}1999 \\
2003 \\
2006\end{array}$ & $\begin{array}{l}1390,6 \\
2385,6 \\
1792,8\end{array}$ & $\begin{array}{l}5,0 \\
4,7 \\
5,1\end{array}$ & $\begin{array}{r}154,5 \\
1341,1 \\
267,4\end{array}$ \\
\hline D31 & $\begin{array}{l}1999 \\
2003 \\
2006\end{array}$ & $\begin{array}{l}12327,6 \\
18541,3 \\
26592,0\end{array}$ & $\begin{array}{l}94,0 \\
87,3 \\
96,3\end{array}$ & $\begin{array}{r}6207,3 \\
11385,0 \\
16284,1\end{array}$ \\
\hline D32 & $\begin{array}{l}1999 \\
2003 \\
2006\end{array}$ & $\begin{array}{r}8123,1 \\
9925,3 \\
16362,8\end{array}$ & $\begin{array}{l}34,7 \\
23,8 \\
31,7\end{array}$ & $\begin{array}{r}5092,5 \\
7678,3 \\
13249,9\end{array}$ \\
\hline D33 & $\begin{array}{l}1999 \\
2003 \\
2006\end{array}$ & $\begin{array}{l}4648,7 \\
5344,6 \\
7444,0\end{array}$ & $\begin{array}{l}39,5 \\
39,4 \\
38,0\end{array}$ & $\begin{array}{r}740,9 \\
1401,5 \\
1851,7\end{array}$ \\
\hline D34 & $\begin{array}{l}1999 \\
2003 \\
2006\end{array}$ & $\begin{array}{l}27460,5 \\
37123,5 \\
70989,9\end{array}$ & $\begin{array}{r}100,1 \\
84,0 \\
113,2\end{array}$ & $\begin{array}{l}18683,2 \\
30676,5 \\
57534,1\end{array}$ \\
\hline D35 & $\begin{array}{l}1999 \\
2003 \\
2006\end{array}$ & $\begin{array}{r}9561,2 \\
9379,0 \\
13088,0\end{array}$ & $\begin{array}{l}85,2 \\
68,4 \\
67,5\end{array}$ & $\begin{array}{r}6402,3 \\
12048,0 \\
12520,5\end{array}$ \\
\hline Ogółem & $\begin{array}{l}1999 \\
2003 \\
2006\end{array}$ & $\begin{array}{l}108192,4 \\
144803,8 \\
226148,2\end{array}$ & $\begin{array}{l}720,9 \\
582,0 \\
638,8\end{array}$ & $\begin{array}{r}49461,4 \\
84337,5 \\
134302,2\end{array}$ \\
\hline
\end{tabular}




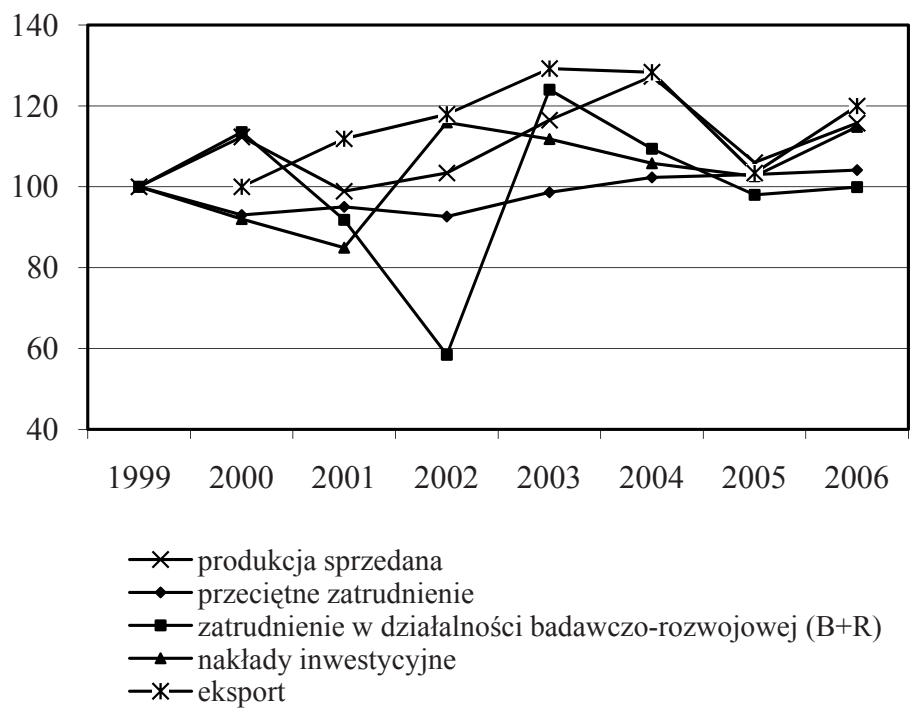

Ryc. 2. Dynamika rozwoju przemysłu wysokiej techniki w latach 1999-2006 na podstawie wybranych mierników (rok poprzedni $=100$ )

Źródło: opracowanie własne na podstawie: Rocznik Statystyczny Przemysłu GUS 2000-2007

a) ogółem

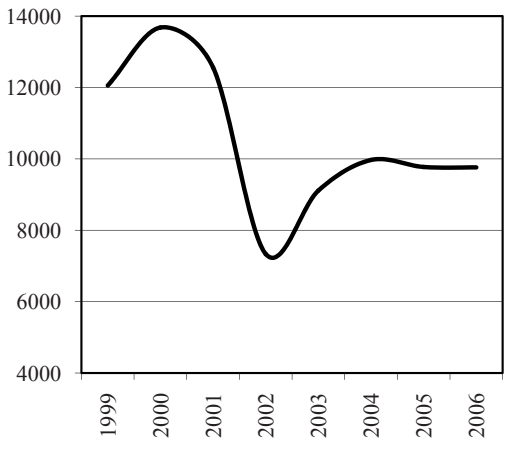

b) w tym

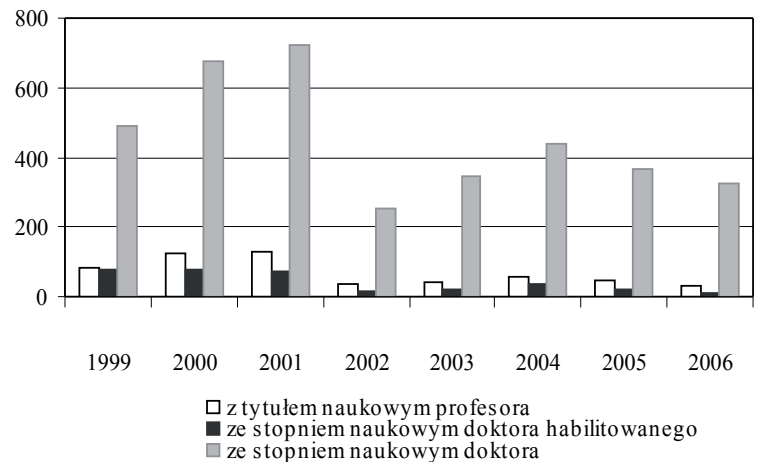

Ryc. 3. Zatrudnieni w działalności badawczo-rozwojowej (B+R) w przemyśle wysokiej techniki w latach 1999-2006²

Źródło: opracowanie własne na podstawie: Rocznik Statystyczny Przemysłu GUS 2000-2007.

Przyjmując podział przedsiębiorstw na trzy klasy wielkości, przeciętna liczba pracujących zmniejszyła się w latach 1999-2006 odpowiednio o 6\%, 3\%, 15\%, przy czym w latach 2003-2006 zdecydowanie aktywniejsze były przedsiębiorstwa duże (ryc. 4). Zróżnicowanie dynamiki przeciętnej liczby pracujących w przemyśle wysokiej techniki w zależności od

${ }^{2}$ Dane dotyczą podmiotów gospodarczych zatrudniających ponad 49 osób oraz jednostek badawczo-rozwojowych pracujących na rzecz przemysłu. 
wielkości przedsiębiorstw wynika m.in. z ponadprzeciętnego wzrostu znaczenia produkcji pojazdów mechanicznych. W latach 2003-2006 przeciętne zatrudnienie w tej branży wzrosło o $35 \%$, tj. 30 tys. osób.

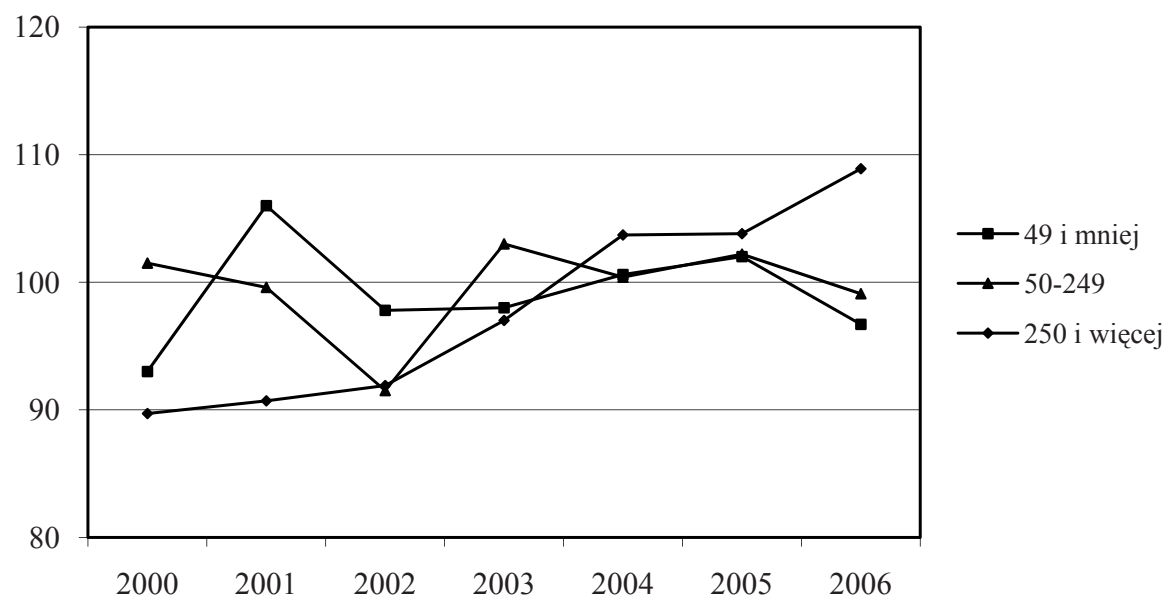

Ryc. 4. Dynamika przeciętnej liczby pracujących w przemyśle wysokiej techniki w latach 1999-2006 według wielkości przedsiębiorstw (rok poprzedni=100)

Źródło: opracowanie własne na podstawie: Rocznik Statystyczny Przemysłu GUS 2000-2007

Przeciętne miesięczne wynagrodzenie brutto w przemyśle ogółem wzrosło o 40\%, natomiast w odniesieniu do poszczególnych branż wysokiej techniki od 9\% (produkcja maszyn biurowych i komputerów) do 53\% (produkcja maszyn i urządzeń). W latach 1999-2004 najwyższy poziom wynagrodzenia charakteryzował produkcję maszyn biurowych i komputerów (3511 zł w 2004 r.). W 2006 roku najwyższe przeciętne miesięczne wynagrodzenie brutto cechowało produkcję chemikaliów ( 3287 zł), a najniższe - niższe o 40\% od najwyższego w przemyśle wysokiej techniki oraz niższe od przeciętnego miesięcznego wynagrodzenia w przemyśle ogółem (2499 zł) - produkcję maszyn i aparatury elektrycznej (2415zł).

W latach 1999-2006 nakłady inwestycyjne w przemyśle wysokiej techniki kształtowały się na poziomie 71,3 mld zł, co stanowiło $22 \%$ wartości nakładów inwestycyjnych w przemyśle ogółem. Analiza dynamiki nakładów inwestycyjnych w przemyśle wysokiej techniki wskazuje m.in. na blisko sześciokrotny wzrost nakładów w latach 2005-2006 w przedsiębiorstwach specjalizujących się w produkcji sprzętu i urządzeń radiowych, telewizyjnych i telekomunikacyjnych, przy czym pod względem wielkości nakładów w poszczególnych momentach czasowych dominowała produkcja pojazdów mechanicznych (ryc. 5). W całym uwzględnionym okresie wartość nakładów inwestycyjnych poniesionych przez przedsiębiorstwa tej branży stanowiła 36\% wartości nakładów w przemyśle wysokiej techniki.

W 2006 roku wartość eksportu produktów wysokiej techniki wynosiła 55,4 mld zł wobec 134,3 mld w roku 2000. Krzywa dynamiki eksportu wyrobów przemysłowych wysokiej techniki podlegała względnie niewielkim wahaniom. Jej przebieg pokrywał się z przebiegiem krzywej dynamiki eksportu wyrobów przemysłowym ogółem. Wśród działów o najwyższej dynamice eksportu w latach 2000-2006 ( $\left.\mathrm{W}_{\mathrm{d}} \geq 300\right)$ znajdują się: produkcja pojazdów mechanicznych - do poziomu 57 mld zł oraz maszyn i urządzeń - 16 mld zł. 


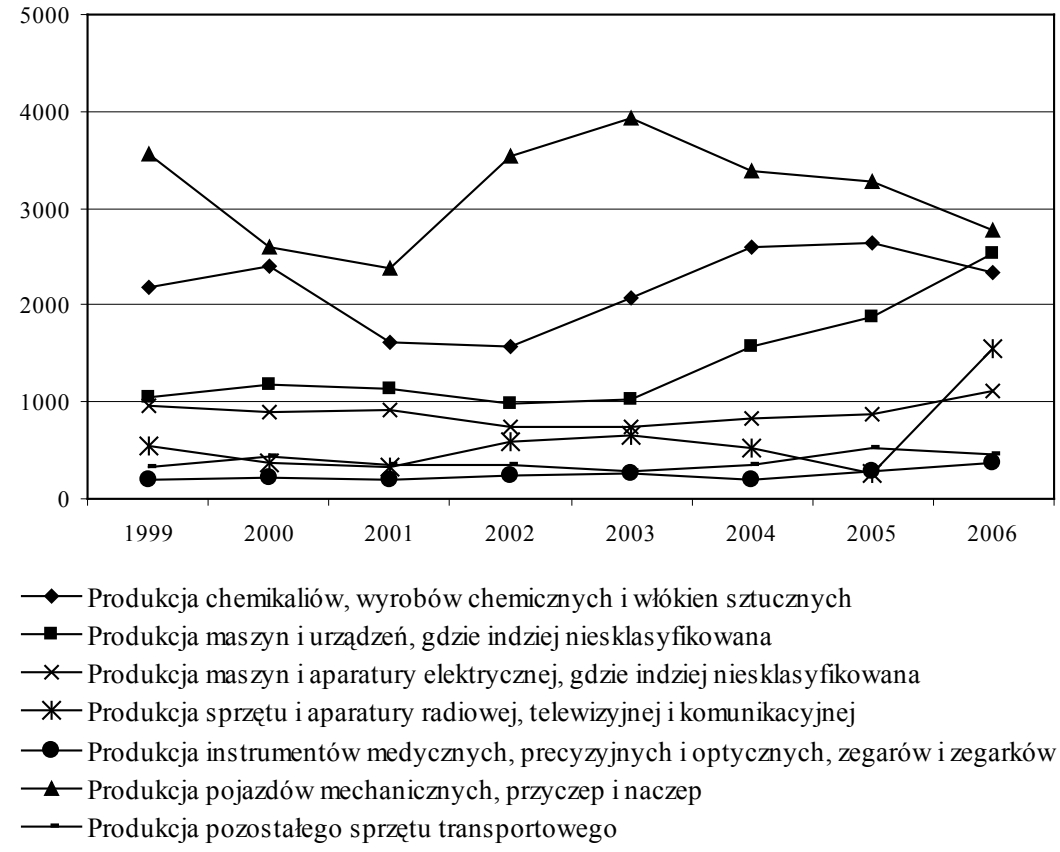

Ryc. 5. Nakłady inwestycyjne w przemyśle wysokiej techniki w latach 1999-2006 według branż (ceny bieżące $\mathrm{w}$ mln zł)

Źródło: opracowanie własne na podstawie: Rocznik Statystyczny Przemysłu GUS 2000-2007

Przyjmując za podstawę analizy ujęcie według klasyfikacji PKD, udział przemysłu wysokiej techniki w produkcji sprzedanej przemysłu zwiększył się z 25\% do 29\%, w eksporcie z $46 \%$ do 50\%, w przeciętnym zatrudnieniu nie zmienił się i kształtował na poziomie $23 \%$. Nawiązując jednak do listy branż i produktów wysokiej techniki ustalonej przez OECD, udział tych branż w ogólnej wartości sprzedaży w 2006 roku wynosił niespełna 4,2\% ${ }^{3}$. Wśród branż high technology o najwyższej dynamice produkcji sprzedanej w latach 1999-2006 $\left(\mathrm{W}_{\mathrm{d}}>200\right)$ znajdują się: produkcja wyrobów farmaceutycznych, produkcja lamp elektronowych i pozostałych elementów elektronicznych, odbiorników telewizyjnych i radiowych, urządzeń do rejestracji i odtwarzania dźwięku i obrazu oraz akcesoriów do nich, sprzętu medycznego i chirurgicznego oraz przyrządów ortopedycznych (ryc. 6). Należy zwrócić uwagę na niespełna trzydziestoprocentowy wzrost przychodów ze sprzedaży maszyn biurowych i komputerów ${ }^{4}$.

${ }^{3}$ Dotyczy przedsiębiorstw zatrudniających powyżej 9 osób (źródło: niepublikowane materiały statystyczne GUS).

${ }^{4}$ W 2007 r. branża ta była reprezentowana przez 19 przedsiębiorstw (zatrudniających powyżej 49 osób), których działalność jest przedmiotem badań prowadzonych przez autorkę. Są to: Optimus SA, Posnet Systemy Kas Fiskalnych sp. jawna, Datrontech Poland sp. z o.o., KT Eureka sp. z o.o. w Warszawie, Elkomtech SA, Dell Products Poland sp. z o.o., Laser Sinex sp. z o.o. w Łodzi, Spółka Inżynierów SIM sp. z o.o., Lanex SA w Lublinie, Sono-Polska sp. z o.o., Alco Electronics sp. z o.o. w Wołowie, HSK-Data LTD sp. z o.o. w Krakowie, Alma SA w Poznaniu, Ever sp. z o.o. w Swarzędzu, Zakłady Urządzeń Komputerowych Elzab SA w Zabrzu, Upos System sp. z o.o. w Knurowie, Novitus SA w Nowym Sączu, Fideltronik Imel sp. z o.o. w Suchej Beskidzkiej, MSI Polska sp. z o.o. w Bielanach Wrocławskich. 


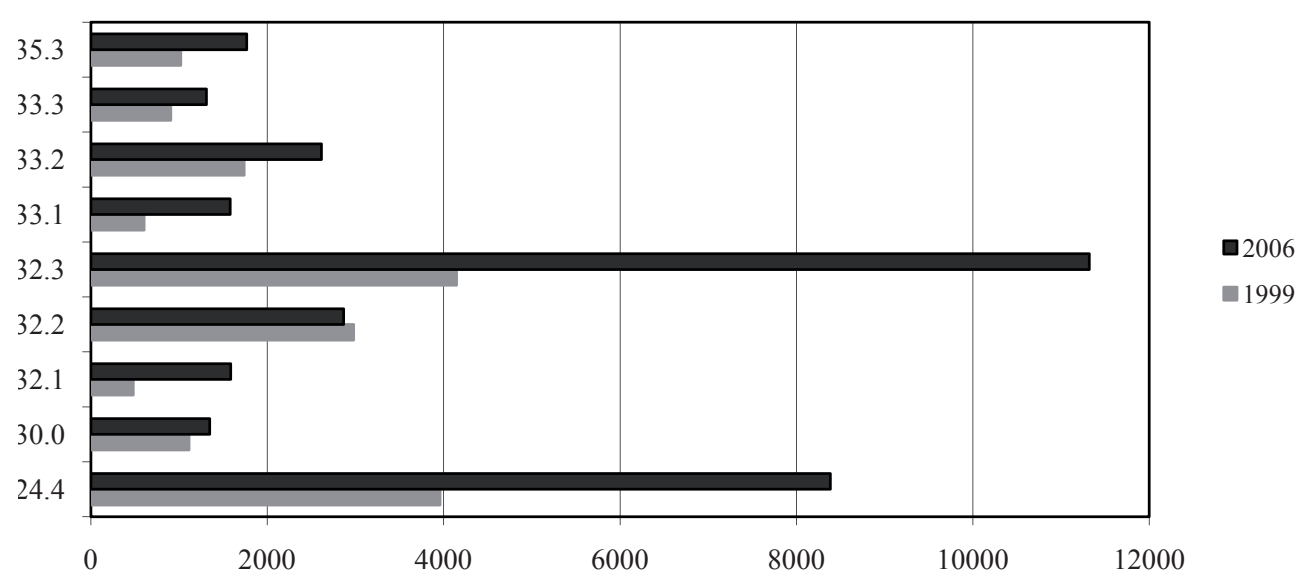

Ryc. 6. Produkcja sprzedana wybranych grup produktów wysokiej techniki (według OECD) w latach 1999 i 2006 (ceny bieżące bazowe w mln zf)

Branże: 24.4 produkcja wyrobów farmaceutycznych, 30.0 produkcja maszyn biurowych i komputerów, 32.1 produkcja lamp elektronowych i pozostałych elementów elektronicznych, 32.2 produkcja nadajników telewizyjnych i radiowych oraz aparatów dla telefonii i telegrafii przewodowej, 32.3 produkcja odbiorników telewizyjnych, radiowych, urządzeń do rejestracji i odtwarzania dźwięku i obrazu oraz akcesoriów do nich, 33.1 produkcja sprzętu medycznego i chirurgicznego oraz przyrządów ortopedycznych, 33.2 produkcja instrumentów i przyrządów pomiarowych, kontrolnych, badawczych, nawigacyjnych i pozostałego przeznaczenia, 33.3 produkcja systemów do sterowania procesami przemysłowymi, 35.3 produkcja statków powietrznych i kosmicznych

Źródło: opracowanie własne na podstawie niepublikowanych materiałów statystycznych GUS

\section{STRUKTURA PRZEMYSŁU WYSOKIEJ TECHNIKI}

W efekcie dynamicznego rozwoju przedsiębiorstw specjalizujących się w produkcji pojazdów mechanicznych udział tej branży w produkcji sprzedanej przemysłu wysokiej techniki zwiększył się w latach 1999-2006 z 25\% do 31\%, w przeciętnym zatrudnieniu z 14 do 18\%, w eksporcie z 38\% do 43\%. Pod względem zatrudnienia dominuje produkcja maszyn i urządzeń (tab. 3). W rozpatrywanym okresie przeciętne zatrudnienie w tej branży zmniejszyło się z 33\% do 29\%.

Rozwój przemysłu wysokiej techniki w Polsce w latach 1999-2006 nie przebiegał W sposób ciągły. W latach 1999-2003 nastąpił spadek przeciętnego zatrudnienia o 20\%, podczas gdy w okresie 2003-2006 branże wysokiej techniki odegrały istotną rolę w tworzeniu miejsc pracy.

Nawiązując do światowych trendów rozwoju branż opartych na osiagnięciach nauki i techniki, Polska charakteryzuje się nadal bardzo niskim udziałem produktów wysokiej techniki w ogólnej wartości sprzedaży. Niezbędne jest globalne podejście do nadrobienia tego zapóźnienia, czemu sprzyja członkostwo w Unii Europejskiej, wsparcie z jej funduszy oraz otwarcie na gospodarkę światową. W kształtowaniu rozwoju sekcji wysokiej techniki istotne znaczenie posiada polityka proinnowacyjna, naukowa, edukacyjna, regionalna (Kukliński 
2001). Jednocześnie należy zwrócić uwagę na relacje między Strategią Lizbońską a możliwościami budowania gospodarki opartej na wiedzy w Polsce (zob. Okoń-Horodyńska, Piech 2005).

Tab. 3. Zmiany struktury przemysłu wysokiej techniki w latach 1999-2006

\begin{tabular}{|c|c|c|c|c|c|c|}
\hline \multirow{2}{*}{ Branże } & \multicolumn{2}{|c|}{$\begin{array}{c}\text { Udział produkcji } \\
\text { sprzedanej }\end{array}$} & \multicolumn{2}{c|}{$\begin{array}{c}\text { Udział przeciętnego } \\
\text { zatrudnienia }\end{array}$} & \multicolumn{2}{c|}{ Udział eksportu } \\
\cline { 2 - 7 } & 1999 & 2006 & 1999 & 2006 & 2000 & 2006 \\
\hline D24 & 22,2 & 21,0 & 16,9 & 16,0 & 13,6 & 12,1 \\
\hline D29 & 19,1 & 18,8 & 33,4 & 28,9 & 11,1 & 12,2 \\
\hline D30 & 1,3 & 0,8 & 0,7 & 0,8 & 0,3 & 0,2 \\
\hline D31 & 11,4 & 11,7 & 13,0 & 15,1 & 12,5 & 12,1 \\
\hline D32 & 7,5 & 7,2 & 4,8 & 5,0 & 10,3 & 9,9 \\
\hline D33 & 4,3 & 3,3 & 5,5 & 5,9 & 1,5 & 1,4 \\
\hline D34 & 25,4 & 31,4 & 13,9 & 17,7 & 37,8 & 42,8 \\
\hline D35 & 8,8 & 5,8 & 11,8 & 10,6 & 12,9 & 9,3 \\
\hline
\end{tabular}

Źródło: obliczenia własne na podstawie: Rocznik Statystyczny Przemysłu GUS 2000, 2001, 2007

W strukturze produkcji sprzedanej przemysłu wysokiej techniki według poziomów techniki udział branż high technology zmniejszył się z 16,8\% do 15,5\% przy wzroście przychodów ze sprzedaży z 17,1 mld zł do 32,9 mld zł.

\section{Podsumowanie I DALSZE PROBLEMY BADAWCZE}

Wymogiem skutecznego konkurowania jest efektywne zarządzanie procesami kreowania i przepływu wiedzy. W efekcie przyspieszenia zmian technologicznych i coraz krótszych cykli życia produktów przedsiębiorstwa w Polsce powinny sprostać globalnej konkurencji.

Wydaje się, że przedmiotem badań traktowanych jako wyznacznik kontynuacji studiów nad efektywnością rozwoju przemysłu wysokiej techniki w Polsce powinny stać się następujące problemy: 1. zachowania przestrzenne i strategie wybranych przedsiębiorstw wysokiej techniki, w szczególności w kontekście aktualnej sytuacji na rynku globalnym, 2. koncepcja przewag konkurencyjnych a funkcjonowanie przedsiębiorstw wysokiej techniki, 3. relacje między aktorami-uczestnikami gry ekonomicznej prowadzącymi działalność na obszarze Doliny Lotniczej oraz w odniesieniu do innych form przestrzennej organizacji produkcji, 4. rozwój przestrzenny przemysłu wysokiej techniki w związku z kształtowaniem i funkcjonowaniem systemu osadniczego pod wpływem rozwijającego się społeczeństwa informacyjnego oraz oddziaływaniem procesu metropolizacji. 


\section{Literatura}

Chojnicki Z., 1999, Podstawy metodologiczne i teoretyczne geografii, Bogucki Wydawnictwo Naukowe, Poznań.

Chojnicki Z., 2003, Polska na ścieżce rozwoju gospodarki opartej na wiedzy. Podejście regionalne, „Przegląd Geograficzny”, 75, 1, s. 23-39.

Chojnicki Z., Czyż T., 2006, Aspekty regionalne gospodarki opartej na wiedzy w Polsce, Bogucki Wydawnictwo Naukowe, Poznań.

Grudzewski W., Hejduk I., 2008, Zarzadzanie technologiami. Zaawansowane technologie i wyzwanie ich komercjalizacji, Centrum Doradztwa i Informacji Difin sp. z o.o., Warszawa.

Kasprzak W., Pelc K., 1999, Wyzwania technologiczne. Prognozy i strategie, Wydawnictwo Profesjonalnej Szkoły Biznesu, Kraków.

Kobyłko G., Morawski M., 2006, Przedsiębiorstwo zorientowane na wiedze, Centrum Doradztwa i Informacji Difin sp. z o.o., Warszawa.

Kukliński A. red., 2001, Gospodarka oparta na wiedzy. Wyzwanie dla Polski XXI wieku, Komitet Badań Naukowych, Warszawa.

OECD, 2000, Knowledge management in the learning society, Paris.

Okoń-Horodyńska E., Piech K. red., 2005, Strategia Lizbońska a możliwości budowania gospodarki opartej na wiedzy w Polsce - wnioski i rekomendacje, Wydawnictwo Polskiego Towarzystwa Ekonomicznego, Warszawa.

Porter M., 1990, The competitive advantage of nations, Macmillan, London.

Porter M., 2006, Przewaga konkurencyjna. Osiaganie i utrzymywanie lepszych wyników, Wydawnictwo Helion, Gliwice.

Przybyszewski R., 2007, Kapitat ludzki w procesie ksztaltowania gospodarki opartej na wiedzy, Centrum Doradztwa i Informacji Difin sp. z o.o., Warszawa.

Toffler A., 2003, Zmiana władzy. Wiedza, bogactwo i przemoc u progu XXI wieku, Wydawnictwo Zysk i S-ka, Poznań.

Welfe W. red., 2007, Gospodarka oparta na wiedzy, Polskie Wydawnictwo Ekonomiczne, Warszawa.

Wieloński A., 2007, Zmiany strukturalne w przemyśle światowym na przełomie wieków, [w:] J. Lach, M. Borowiec, T. Rachwał red., Procesy transformacji społeczno-ekonomicznych i przyrodniczych struktur przestrzennych, Wydawnictwo Naukowe AP, Kraków.

Woroniecki J., 2003, Nowa gospodarka - ułuda czy rzeczywistość, „Ekonomista”, nr 5.

Zioło Z., 2008, Procesy transformacji przemystowych układów przestrzennych na tle zmieniajacego się otoczenia, [w:] Z. Zioło, T. Rachwał red., Procesy transformacji układów przestrzennych przemystu na tle zmieniajacego się otoczenia, Prace Komisji Geografii Przemysłu PTG, nr 10, Warszawa-Kraków.

\section{Efficiency of the development of high-tech industry in Poland}

In the age of the emergence of information society, economic growth is increasingly dependent on the production, distribution and use of knowledge. The new, dominating role of science in economic and civilizational development boosts the prestige of technological sciences. Technological advances are among the most crucial factors affecting competition rules. They play a key role in both the processes leading to structural changes within an industrial branch and in the formation of new branches.

The aim of the present paper is to analyse and assess the efficiency of the development of high-tech industry in Poland in the light of the science-related growth and transformation of the economy and the special role the industry plays in the working-out and maintenance of the competitive advantage of a country. 
From the perspective of world tendencies in the development of branches based on scientific and technological advances, Poland still displays a very low proportion of high-tech goods in total sales. What is needed is a global approach to the catching-up process, which is facilitated by the country's membership in the European Union, support from the EU funds, and opening to the world economy.

\section{dr Anna Świdurska}

Uniwersytet im. Adama Mickiewicza w Poznaniu

Instytut Geografii Społeczno-Ekonomicznej i Gospodarki Przestrzennej

e-mail: amswid@amu.edu.pl 